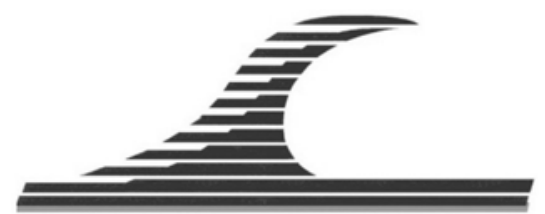

Revue Paralia, Volume 8 (2015) pp s03.1-s03.5

Keywords: Coastline, Beach, Zemmouri El-Bahri, Boumerdes, Sandpits, Dunes, Beach profile.

(C) Editions Paralia CFL

\title{
Exploitation of beach sand and coastal dunes. Impact on the equilibrium of coastline between Boumerdes and Zemmouri El-Bahri (East Algiers), Algeria
}

\section{Hanifa HABIKI ${ }^{1}$, Lazreg BENSLAMA ${ }^{1}$}

1. Laboratoire de Géo-Environnement, U. des Sciences et Technologie H. Boumediene. Alger, Algérie.

hbenslama@gmail.com

\begin{abstract}
:
Overexploitation of the sand of the coastal dunes and beaches, causes an imbalance in the fragile coastal area and exposes it to the aggressive action of the sea. The case of beach Zemmouri and Boumerdes El-Bahri is edifying. The beach is bordered by a set of two juxtaposed coastal dunes. One directly along the beach which is commonly called active dune, the other named ancient dune is in second position towards the continent. Two main phenomena, first the erosive action of the sea and also the overuse of sandpits are the major causes of coastal degradation. We are witnessing a disappearance of the active dune and partial destruction of the ancient dune. In some places, depressions are created which facilitate the intrusion of marine waters. In order to study this phenomenon, we have conducted beach profiles with a frequency of a survey every two months for a year.
\end{abstract}

Translated version of a paper in French (DOI reference: $h$ ttp://dx.doi.org/10.5150/cmcm.2015.031), presented during the edition 3 of the Coastal and Maritime Mediterranean Conference, (25-27 November 2015) in Ferrara, Italy. Received 26 June 2015, accepted 11 December 2015, available online 30 January 2016.

How to cite this paper:

HABIKI H., BENSLAMA L. (2015). Exploitation of beach sand and coastal dunes. Impact on the equilibrium of coastline between Boumerdes and Zemmouri El-Bahri (East Algiers), Algeria. Revue Paralia, Vol. 8, pp s03.1-s03.5.

DOI: http://dx.doi.org/10.5150/revue-paralia.2015.s03 


\section{Materials and methods}

The levelling was carried out using a Wild T16 theodolite and a levelling rod. The apparatus set at profile head station, was operated at each inflection (visible change in slope) by simultaneous measurement of distance by direct aiming and altimetry by horizontal aiming on the rod.

\section{Introduction}

According to PASKOFF (1985) the mean sea level may be affected by oscillations limited in time, such as waves and slight fluctuations due to seasonal phenomena (variation of the flow of ocean currents, atmospheric pressure, prevailing winds and the density of sea water). Major events can shape the coastline and tidal waves breaking. The amplitude of the tide is very low or practically zero on the Algerian coast, hence its insignificant influence.

Bay Zemmouri is wide open to the influence of ocean conditions. Therefore, there are variations of the coastline, sometimes spectacular.

The beaches are lined with at their south end by sharp dunes and old more or less fixed dunes with vegetation. These dunes constitute a natural protection, resulting in a dynamic equilibrium of the beach.

The detrital supplies of the wadi Isser essentially and to a lesser extent those from the wadi Sebaou are involved in the feeding of submarine and aerial beaches and wrinkles front coast.

The coarse material exceeding 500 micrometres, brought during floods is deposited at the mouths then redistributed tangentially by littoral drift currents. It constitutes in most places the runup part of which is taken up by the rip currents and feeds the sand waves in shallow water. These wrinkles constructed by the swell, introduce two types of irregularities in the particle size distribution. The top of the wrinkles is underlined by the presence of coarse sediment (median greater than 300 micrometres) because of the greater agitation of the water as a result of breaking waves swell. The furrow is very often filled up by fine material, which found there a favourable shelter for its deposition; the same observation was made in the Ebro delta (GUILLEN \& PALANQUES, 1993). The mobility of these wrinkles seems to be directly related to the evolution of the aerial beaches morphology.

The more or less fine sands respond to the coastal and subtidal marine dynamics. They feed seabeds favorable to their deposit but also transit along the coast under the influence of longshore currents and so supply the aerial beaches. These are subjected to eolian deflation which results in the formation and/or feeding of the current active dunes. These formations are the subject of most intense and even abusive aggregate exploitations that resulted in their total destruction causing more often catastrophic situations. To identify these problems, fourteen series of topographic beach profiles surveys perpendicular to the coast has been made at approximately two month intervals 
over an annual cycle from November 1983 to October 1984. This study concerned two great beaches: that of Zemmouri and Figuier. Four stations (V, XI, XIII and XVI) have been chosen in order to illustrate the consequential changes observed for the fattening and erosion of these beaches (figure 1).

These profiles (figure 2) show significant widths of beach in summer (May and July topographic surveys) sign of a feeding and an erosion in winter (October and November topographic surveys). This classical pattern is upset because some profiles in a particular situation show erosion in summer and accretion in winter.

These latter are located in areas of exploitation of sand pits. It results in the over deepening of the beach occasioned by the machines acting in summer. During the unfurling, the sea invades the artificial depressions causing the disappearance of a portion of the beach. This phenomenon is quite visible on stations XIII and XVI.

In addition on station $\mathrm{V}$, the comparison of the beach profile of the month of November 83 (winter) and the topographic profile of July 84 (summer) shows an increase in the width of the beach.

In March, there is a sediment filling on the first 40 metres of the profile as compared to November, followed by a total disappearance of the beach. In May, the profile shows a lowering of one metre at the inflection point. In July, at the first inflection of the profile, the beach shows a fattening approximatively 1.5 metre high and 20 metres wide compared to November. In October, there is a further deepening.

In fact these over deepening that occur after filling of the topographic profile surveys can be explained by the overexploitation of sand pits.

In the absence of any controls, we found it virtually impossible to quantify this both natural and anthropogenic erosion.

The natural equilibrium was also disrupted by the sand exploitation upstream of the estuary along the bed of the wadi Isser and by the retention of sediment supply following the construction of the Beni Amrane dam. 


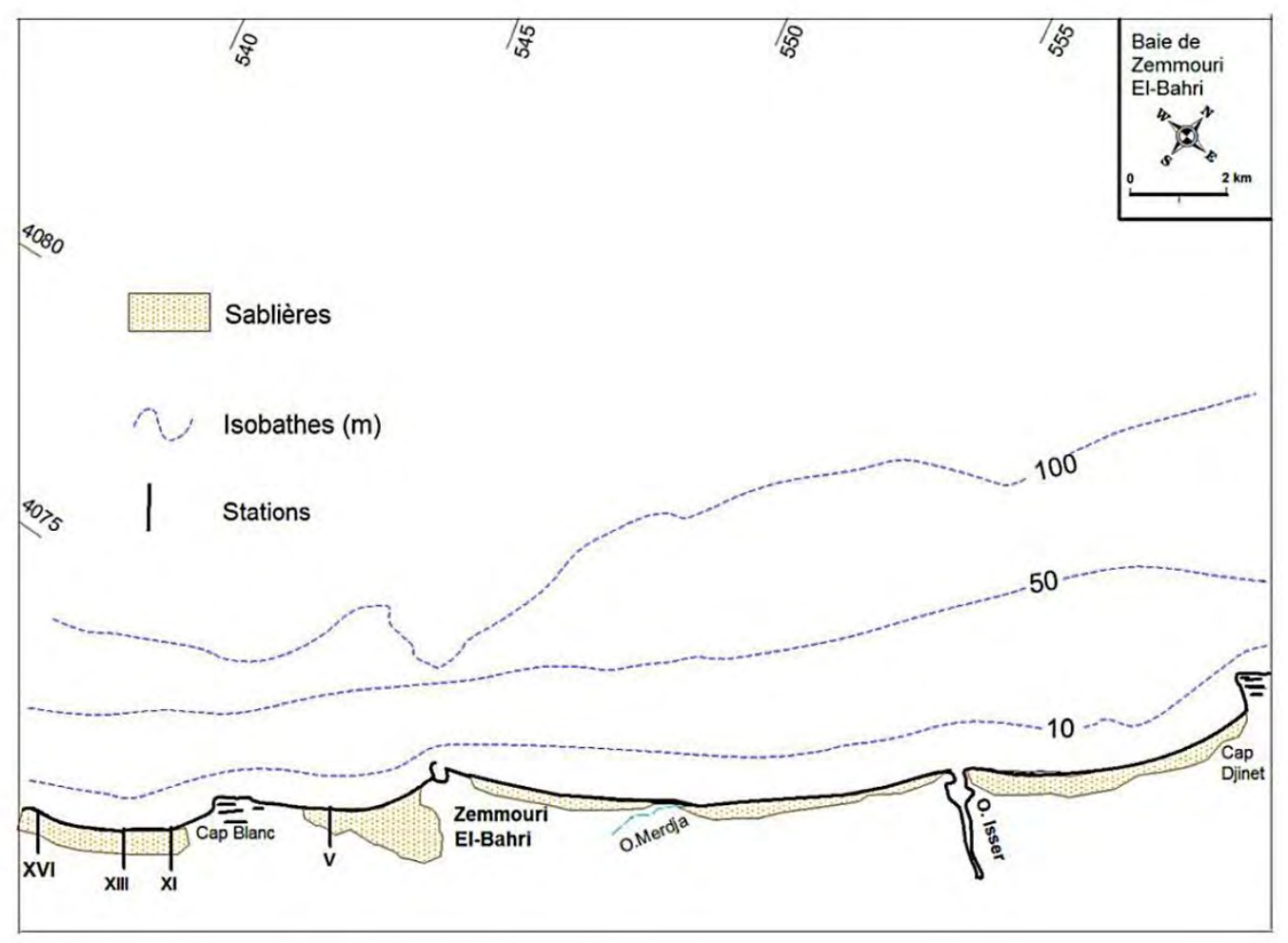

Figure 1. Location of beach profiles and sand pits

(Sablières = Sand Pits).
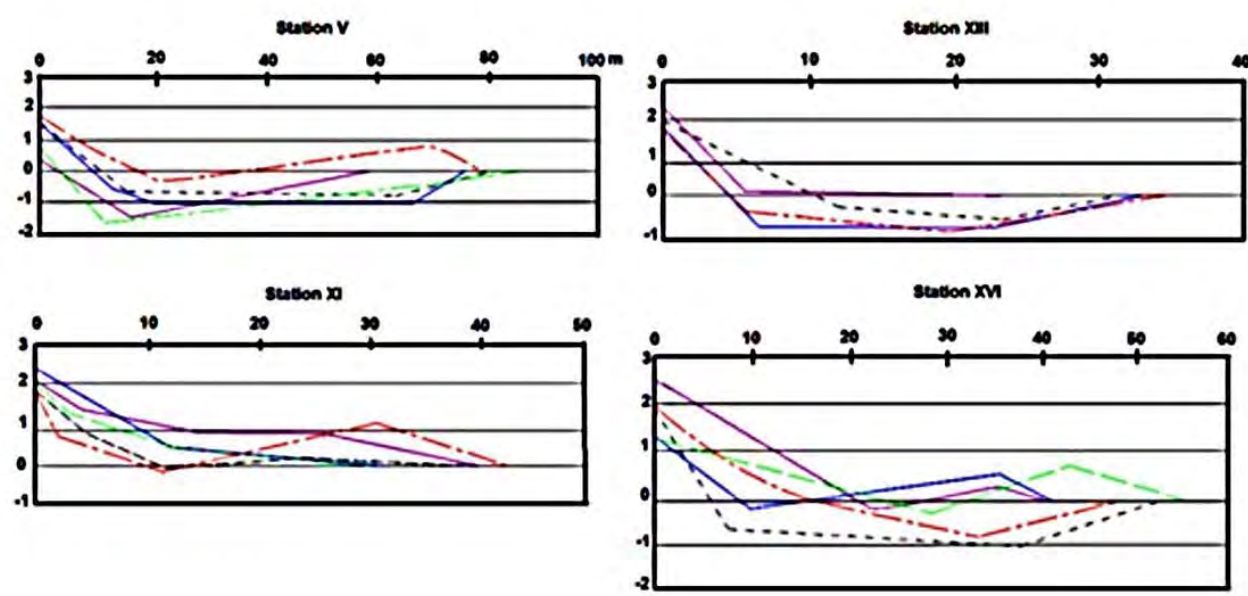

oer11/1963

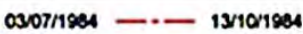

Figure 2. Beach profiles between Boumerdes and Zemmouri. 


\section{Conclusion}

The morphological variations of the coastline and the mobility of the most important front coast ridges are seen during periods of major storms.

Longshore bars are moving towards the coast, the sea invades the beach which is shrinking in winter. During the summer, the ridges move seaward, consequently the beach is more developed.

The intervention of man to extract the sand can change this classical pattern the erosion will take place in summer, the conditions being favorable for the exploitation of sand pits without any meteorological constraint.

The displacement of the ridges and the occupation of their summit by coarse materials are consequences of the rip currents, responsible for their building and the selection of the size of their components.

\section{References}

GUILLEN J., PALANQUES A. (1993). Longshore bar and trough systems in a microtidal, storm-wave dominated coast: The Ebro Delta (Northwestern Mediterranean). Marine Geology, Vol. 115, pp 239-252. http://dx.doi.org/10.1016/00253227(93)90053-X

PASKOFF R. (1985). Les littoraux. Impact des aménagements sur leur évolution. Collection Géographique, Ed. Masson, Paris, 186 p. 